\section{Reforming the Upper House: Lessons from Britain $^{1}$}

\section{Gary Levy ${ }^{\star}$}

For nearly two decades Britain has been engaged in some of the most ambitious constitutional and parliamentary reforms since the Reform Acts of the nineteenth century. Reform in the House of Lords alone has produced six White Papers, one Royal Commission, and dozens more parliamentary votes and reports by the House of Commons, the House of Lords and the joint committees. Canadians have watched these developments with particular interest, since many of the issues debated - the legitimacy of an Upper House, election versus appointment, and qualifications for membership - are similar to those discussed here. Yet before looking at possible lessons for Canada we need to reflect upon another question: What is the Westminster Model and what elements of this model are reflected in our own system?

\section{Defining the Westminster Model}

The common practice is for Canadians to simply proclaim ourselves adherents to the Westminster Model of the United Kingdom but, unfortunately, there is little agreement as to what rules and institutions precisely constitute this model.

Phillip Norton argues that the essence of the Westminster Model is the concept of Her Majesty's Loyal Opposition. ${ }^{2}$ Others define it in terms of criteria which include, for instance, a first-past-the-post electoral system where two major parties win the vast majority of the seats, an impartial Speaker, executive dominance over the legislature, responsible government, and the confidence convention. None of these, however, is exclusive to the Westminster Model.

At one time anything coloured red on the British imperial map or in places where the Speaker wore a wig were loosely considered a 'Westminster' system. Between 1944 and 1961, nearly 100 constitutional instruments were produced by the British Colonial Office primarily for nations in Asia and Africa, and the Westminster Model was usually the model of choice.

The need to distinguish between countries where the model was exported to areas without established institutions (Canada, Australia, New Zealand and the Caribbean), and those places where it was imposed on older existing cultures (Africa and Asia), soon became apparent. ${ }^{3}$ The recipients in the latter category often demonstrated "that the Westminster Model can hardly be expected to operate unchanged in countries with different cultures and social systems."

More recent studies of Westminster systems tend to be limited to the 16 members of the Commonwealth who still recognize the Queen as their Head of State. For many scholars, the term is only used for three of the four original Dominions: Canada, Australia and New Zealand.

Yet many Australians refer to their system as the "Australian model," and New Zealand has undergone significant changes since it adopted 
proportional representation in 1996. I would argue that one element at the heart of the Westminster Model and shared by Canada and the United Kingdom, but not Australia and New Zealand is the appointed Upper House as an essential part of our mixed constitution.

Not to be confused with the later idea of checks and balances, a mixed constitution, according to Aristotle ${ }^{5}$, brought together the hereditary monarchy, the landed aristocracy and the democratic element. The modern equivalents are a constitutional monarchy, an appointed meritocracy, and a chamber elected democratically by universal suffrage. This is the theory underlying the Westminster model. It postulates that good governance derives from the bringing together of actors from these three different perspectives.

An upper house crafted using the Westminster Model is not an example of an American style checks and balances and its composition of appointed men and women of experience and merit makes it well suited to curb political expediency, dogmatic posturing, and impulsive responses that governments and political parties are prone to. Ideally, it brings to bear in its work of scrutiny, the influence of common sense, mature judgement and a wider sense of the public interest. ${ }^{6}$

\section{Several Important Differences Between the Senate and the House of Lords}

The first difference is that the power of the Lords was curbed by the Parliament Act, 1911. In 1906 the Liberals had won a large majority but their budget was defeated by the Conservative majority in the Lords. After being re-elected, the Liberals brought forth a bill to curtail the Lords ability to amend or veto money bills. The Parliament Act as subsequently amended in 1949, now limits the ability of the Lords to delay most bills passed by the Commons for one year. ${ }^{7}$ Money Bills, designed to raise money through taxes or to spend public money, must start in the Commons and must receive Royal Assent no later than a month after being introduced in the Lords, even if the Lords has not passed them. The Lords cannot amend Money Bills. No such time limitation exists in Canada except for constitutional amendments which can only be delayed by the Senate for six months.

A second difference is the existence of the Salisbury-Addison Convention which in 1945 addressed_the possibility of obstruction of Bills by the Upper House. When the post-war Labour Government found itself with virtually no members in the House of Lords, it negotiated an agreement which provided that the Lords would not obstruct Bills that sought to implement policies clearly outlined in an election manifesto. This decision did not affect the House's ability to amend legislation. The convention still governs relations between the chambers to some extent, ${ }^{8}$ although the advent of a coalition government in 2010 complicates the process since the Coalition Agreement was a mixture of the manifestos of two different parties. ${ }^{9}$ No such written convention exists in Canada where the Senate frequently delays legislation if the majority in the Upper House is not from the same party as the government.

The third key difference is the absence of any upper limit on the membership in the House of Lords. For centuries it was a small body with 50 or so members but, as its powers declined, membership grew to well over 1000 before the removal of most hereditary peers in 1999. As of October 2013 there were over 800 members. In terms of party breakdown, there are 219 Labour, 217 Conservatives, 95 Liberal Democrats, and 183 crossbenchers in the House of Lords. In addition, the House holds 22 Lords Spiritual, a few representing other parties, and 50 or so who are on leave of absence, retired, or suspended. ${ }^{10}$ In Canada, of course, the present upper limit is 104.

A fourth difference between the House of Lords and the Senate is the existence of many independent Lords in the United Kingdom, referred to as crossbenchers. In 1958, the Life Peerages $A c t^{11}$ provided for appointments for life rather than the traditional hereditary appointments that were handed down from father to first born son. This completely changed the composi- 
tion and atmosphere of the British parliament's Upper House. Aside from allowing women to sit, a number of life peers chose to sit as independents without any party affiliation. They became known as "crossbenchers", and their numbers have increased over the years. Only a few crossbenchers, such as former Speakers of the House, come from a political background. Others are drawn from professions such as medicine, science, business, the voluntary sector, and the performing arts. Most are still actively involved in their professions. They do not have a party Leader but many of those functions are performed by a Convener ${ }^{12}$ There is no such position as Convener of Independent Members in Canada since most Senators have a party affiliation.

A fifth differences concerns the British approach to appointment in practice, if not in theory. An informal custom has developed of alternating party appointments among the party leaders so that all parties have significant representation in the Upper House. The Coalition Agreement sets a goal that political representation should roughly reflect the percentage of votes cast for each party in the most recent election. Labour is still over-represented according to this formula, but without a membership limit a Prime Minister could appoint more Lords to attain his share of the vote after an election. Alternately a number of Lords from the losing party could resign, thereby keeping the proportion the same without an increase in total members. In Canada it is rare, although not completely unprecedented, for a Prime Minister to appoint someone from a party other than his own. One final difference between the House of Lords and the Senate is that unlike Canada, the members of the House of Lords do not receive a salary. ${ }^{13}$

\section{The Reform Movement in the UK: 1997-2013}

In the 1997 election, the British Labour Party embarked on an ambitious constitutional and political agenda which included a "more democratic and representative" second chamber. This led to a series of developments, shown in the following tables.

\section{The House of Lords Act}

The first major reform was in the form of the 1999 House of Lords Act. Originally proposed to expel all hereditary peers from the Upper House, the Government accepted an amendment as a two-step approach to this rather radical reform. The amended Bill required that two royal officeholders, the Earl Marshal and Lord Great Chamberlain, would retain their seats, as would 90 additional hereditary peers chosen in an election held by the Lords. The 90 peers who remained were elected by their colleagues and provisions were added for by-elections to take place upon the death of a hereditary peer.

One result of the 1999 reform was to reduce overall membership from 1330 to 669. Hundreds of opposition peers were removed, leading to the prediction that the House of Lords' function would be severely limited. Conversely, the House has actually become more balanced, with no party having an overall majority and with the balance of power resting with the Liberal Democrats and the crossbench independents. The result has been a more assertive and self-confident House that is less concerned about challenges to its legitimacy. ${ }^{14}$ Electing hereditary peers also contributed to a stronger House of Lords, as the most active and committed peers were generally the ones who survived.

One manifestation of the new assertiveness was an increase in the number of defeated government measures. During the Blair years there were 450 such defeats, with 88 in 2002 alone. The number has declined somewhat, not because the upper house is less vigilant but because ministers have become more willing to engage with the Lords before sending Bills to them. The Constitutional Unit of University College maintains a database that depicts the number of defeats, ranging from minor technical issues to major policy issues in the area of finance, security and criminal law. ${ }^{15}$ 


\section{Reforms Under the Coalition 2010-2013}

\begin{tabular}{|c|c|c|}
\hline 1999 & $\begin{array}{l}1^{\text {st }} \text { Labour White } \\
\text { Paper on Reform }\end{array}$ & $\begin{array}{l}\text { Modernising Parliament: Reforming the House of Lords proposes the creation of a } \\
\text { Royal Commission on Reform of the Lords. }\end{array}$ \\
\hline 1999 & House of Lords Act & The Act removes the right of all but 92 hereditary peers to sit in the House of Lords. \\
\hline 2000 & $\begin{array}{l}\text { Royal Commission } \\
\text { report }\end{array}$ & $\begin{array}{l}\text { A House for the Future makes } 132 \text { recommendations including a House with } 550 \\
\text { Members, of which } 65,87 \text { or } 195 \text { are elected. The majority are to be appointed for } \\
12 \text { to } 15 \text { year terms. Party appointment is to be proportional to the results of the last } \\
\text { general election. }\end{array}$ \\
\hline 2000 & $\begin{array}{l}\text { House of Lords } \\
\text { Appointments } \\
\text { Commission created }\end{array}$ & $\begin{array}{l}\text { Two main duties are illustrated; to vet all appointments for "propriety" and, more } \\
\text { importantly, to appoint members to the Crossbenches. Not a statutory body, }\end{array}$ \\
\hline 2001 & $\begin{array}{l}2^{\text {nd }} \text { Labour White } \\
\text { Paper on Reform }\end{array}$ & $\begin{array}{l}\text { The House of Lords - Completing the Reform sets out a ten-year plan for reform. It } \\
\text { proposes reducing the size to } 600 \text {. Parties would nominate a total of } 332 \text { members } \\
\text { based on the proportion of the vote in the last general election. At least } 20 \% \text { of the } \\
\text { House should be non-party appointments. The remaining } 92 \text { hereditary peers would } \\
\text { lose the right to sit. }\end{array}$ \\
\hline 2002 & $\begin{array}{l}\text { Report of House } \\
\text { Select Committee } \\
\text { on Public } \\
\text { Administration }\end{array}$ & $\begin{array}{l}\text { The Second Chamber: Continuing the Reform recommends that } 60 \% \text { of the seats in the } \\
\text { House of Lords be filled through elections. The government response proposes setting } \\
\text { set up a joint committee to present a series of options on which both Houses would } \\
\text { vote. }\end{array}$ \\
\hline 2002 & $\begin{array}{l}\text { Joint Committee } \\
\text { on House of Lords } \\
\text { Reform }\end{array}$ & $\begin{array}{l}\text { The Joint Committee presents seven options for reform. These options are put to a vote } \\
\text { in February 2003, but no consensus occurs. }\end{array}$ \\
\hline 2003 & $\begin{array}{l}\text { 3rd Labour White } \\
\text { Paper on Reform }\end{array}$ & $\begin{array}{l}\text { Constitutional Reform: Next Steps for the House of Lords proposes to remove the } \\
\text { remaining hereditary peers, put the appointments committee on a statutory basis, and } \\
\text { cap the size of the Chamber at } 600 \text {. It is opposed by those who felt it would solidify } \\
\text { an appointed-only Chamber. }\end{array}$ \\
\hline 2005 & $\begin{array}{l}\text { Report of Cross } \\
\text { Party Group of } \\
\text { MPs. }\end{array}$ & $\begin{array}{l}\text { Entitled Breaking the Deadlock, this report by a group of MPs proposes a } 70 \% \text {-elected } \\
\text { House and included a draft Bill to that effect. }\end{array}$ \\
\hline 2005 & $\begin{array}{l}\text { Constitutional } \\
\text { Reform Act }\end{array}$ & $\begin{array}{l}\text { This Act modifies the office of Lord Chancellor and the judicial appointment process. It } \\
\text { also provides for a Supreme Court and for the election of a Lord Speaker. }\end{array}$ \\
\hline 2007 & $\begin{array}{l}4^{\text {th }} \text { Labour White } \\
\text { Paper on Reform } \\
\text { and vote in } \\
\text { Parliament }\end{array}$ & $\begin{array}{l}\text { House of Lords: Reform presents several options, including an all-appointed House, an } \\
\text { all-elected House, and a hybrid option. This time the government's preference is the } \\
\text { hybrid option. It was put to a vote in March 2007. A few months later, Gordon Brown } \\
\text { replaces Blair as PM. }\end{array}$ \\
\hline 2008 & $\begin{array}{l}5^{\text {th }} \text { Labour White } \\
\text { Paper on Reform } \\
\text { and House of } \\
\text { Commons Response }\end{array}$ & $\begin{array}{l}\text { An Elected Second Chamber: Further reform of the House of Lords proposes a largely } \\
\text { elected second chamber but no specific breakdown. Elected and appointed members } \\
\text { would serve three non-renewable terms, totalling } 12 \text { to } 15 \text { years. Three options are } \\
\text { also presented in the paper on the timing of the removal of peers. The House of } \\
\text { Commons Public Administration Select Committee responds to the White Paper, but it } \\
\text { only addresses the appointments process. }\end{array}$ \\
\hline 2009 & $\begin{array}{l}\text { Constitutional } \\
\text { Reform and } \\
\text { Governance Bill }\end{array}$ & $\begin{array}{l}\text { The Bill includes some provisions from the } 5^{\text {th }} \text { White Paper. Although it is adopted } \\
\text { by the House, it is opposed by the Lords and allowed to expire when Parliament is } \\
\text { dissolved for the } 2010 \text { election }\end{array}$ \\
\hline
\end{tabular}




\section{Reforms Under the Coalition 2010-2013 - continued}

\begin{tabular}{|c|c|c|}
\hline 2010 & $\begin{array}{l}\text { General election } \\
\text { returns hung Parliament }\end{array}$ & $\begin{array}{l}\text { Three major party manifestos all include the House of Lords reform. Liberal } \\
\text { Democrats are the most enthusiastic supporters of an elected Upper House. The } \\
\text { Conservatives see the reform of the Lords as a third-term issue. }\end{array}$ \\
\hline 2010 & $\begin{array}{l}\text { Conservative-Liberal } \\
\text { Democrat Coalition } \\
\text { Agreement }\end{array}$ & $\begin{array}{l}\text { The parties commit to establishing a committee to bring forward proposals for a } \\
\text { wholly or mainly elected chamber on the basis of proportional representation. As } \\
\text { an interim measure, they agree that the appointment of new peers would reflect } \\
\text { shares of the vote secured by the political parties in the last general election }\end{array}$ \\
\hline 2011 & $\begin{array}{l}\text { 1st Coalition White } \\
\text { Paper on Lords Reform }\end{array}$ & $\begin{array}{l}\text { The paper calls for an } 80 \% \text { elected chamber, similar to the previous proposal. The } \\
\text { draft Bill is sent to the new Joint committee }\end{array}$ \\
\hline 2011 & $\begin{array}{l}\text { Draft House of Lords } \\
\text { Reform Bill }\end{array}$ & $\begin{array}{l}\text { The Bill proposes a } 300 \text {-member hybrid house, of which } 80 \% \text { are elected. It is sent } \\
\text { for study to a Joint Committee }\end{array}$ \\
\hline 2012 & $\begin{array}{l}\text { Report of Joint } \\
\text { Committee }\end{array}$ & $\begin{array}{l}\text { The Report calls for a three-stage transition process that would result in } 360 \text { elected } \\
\text { members, } 90 \text { appointed members, all serving a } 15 \text { year term with no hereditary } \\
\text { peers. }\end{array}$ \\
\hline 2012 & $\begin{array}{l}\text { Revised Reform Bill } \\
\text { introduced in the } \\
\text { House }\end{array}$ & $\begin{array}{l}\text { The government accepts many of the recommendations of the Joint Committee, but } \\
\text { rejects one key recommendation -that the proposal be subject to a referendum } \\
\text { before it is put into effect. The House adopts the Reform Bill at second reading, but } \\
91 \text { Conservatives vote against it despite a three-line whip and } 19 \text { others abstaining } \\
\text { Many Labour members say they would oppose the programming motion (time } \\
\text { allocation) needed to get it considered in the committee. }\end{array}$ \\
\hline 2012 & $\begin{array}{l}\text { Abandonment of Lords } \\
\text { reform proposal. }\end{array}$ & $\begin{array}{l}\text { In August, Nick Clegg announces the entire package of Lords Reform had been } \\
\text { abandoned, claiming that the Conservatives had "broken the coalition contract." } \\
\text { However, David Cameron disputes this view, saying that the agreement contains no } \\
\text { specific promise to enact House of Lords reform. }\end{array}$ \\
\hline 2013 & $\begin{array}{l}\text { Report of House of } \\
\text { Commons Political and } \\
\text { Constitutional Reform } \\
\text { Committee }\end{array}$ & $\begin{array}{l}\text { House of Lords Reform: What next? Focuses on a range of small scale reforms } \\
\text { to reduce the size of the House of Lords, including such things as a moratorium } \\
\text { on appointments, a compulsory retirement age, abolishment of the remaining } \\
\text { hereditary peers, fixed term appointments for new peers, expelling peers convicted } \\
\text { of a serious offense. }\end{array}$ \\
\hline
\end{tabular}

\section{Creation of the Appointments Commission}

The second reform was the creation of an Appointments Commission in April 2000 as advocated in the Royal Commission chaired by Lord Wakeham. The report recommended the Commission be established by statute, but it was created by the government and several reports have recommended that it be given a firmer basis in statute. ${ }^{16}$

Nevertheless, the Commission is an independent, advisory body that consists of six mem- bers and a Chair. The Conservatives, Labour and Liberal Democratic parties each have one member of the House of Lords on the Commission, who have been nominated by the party leader for three-year terms. The remaining three members and the Chair are non-partisan, with no party affiliations. The Commission's current Chair is the crossbench Lord Ajay Kakkar, a Professor and Surgeon at University College in London.

The Commission has two main functions: It recommends individuals for appointment as crossbench peers, and it vets nominations for life peers, including those nominated by political 
parties. Since the Committee's establishment in 1997, it has recommended more than 60 people for appointment, in a process similar to a job application for the public service, a university or a corporation. Five thousand people have applied since 2000, and since its application process is ongoing, the Committee is continuously evaluating candidates. ${ }^{17}$

Selection and assessment criteria for prospective candidates are published in full on the Commission's website. ${ }^{18}$ The Commission recommends individuals for the crossbench positions based on merit and their ability to make a significant contribution to the House's important work. It also considers nominees who would broaden the expertise and experience of the existing House and reflect the diversity of the United Kingdom. Its mandate is to ensure that the individuals it recommends are independent, have integrity and are committed to the highest standards of public life.

In 2010, a study from the University College in London examined the Commission's appointments since its inception. The study found that of the 63 appointments, 23 were women and 13 were from a minority ethnic background, totalling $37 \%$ and $22 \%$ of the Commission's appointments respectively. These numbers are comparable with the current composition of the Lords, where just over $20 \%$ of Members are women and $5 \%$ are from minority ethnic backgrounds. The study also identified the range of expertise in the House, and concluded that there were one or two areas, such as science, that were underrepresented.

The Commission typically interviews six or seven people before making a recommendation. ${ }^{19}$ The Prime Minister decides the actual number of appointments the Commission may make in a year. In 2012, and after having averaged six appointments a year since its inception, Prime Minister Cameron asked that it make no more than two recommendations a year. All Prime Ministers since Tony Blair have stated they will only decline to pass on a Commission recommendation to the Queen in exceptional circumstances.
The Commission also has a role in vetting individuals nominated to the House of Lords by the Prime Minister and political parties. It is not asked to comment on the suitability of those so nominated, but simply to advise the Prime Minister on the propriety of individual nominees. It also does not have a right of veto over any party nomination. ${ }^{20}$ The Commission takes the view that, in this context, propriety means:

i) the individual should be in good standing in the community in general and with the public regulatory authorities in particular; and

ii) the past conduct of the nominee would not reasonably be regarded as bringing the House of Lords into disrepute. ${ }^{21}$

The Commission's advice to the Prime Minister is confidential and it does not disclose or comment on either the identity or the number of nominees it may have advised against. However, in 2005 the Prime Minister submitted a list of 28 nominees for appointment in the usual way. Publication of the list was delayed and stories began to appear in the press, stating that the Commission had concerns about some of those nominated because they had made large loans and donations to the Labour Party.

Following publication of the list of appointees, minus certain names who had withdrawn or been rejected, ${ }^{22}$ a police investigation was launched into what became known as the "Cash for Honours Scandal." Ultimately no one was convicted, but the police questioned the Prime Minister and arrested a member of the Lords who was subsequently released on bail. These events contributed to the declining support for the Labour Party.

Some observers initially believed the involvement of the Appointments Commission may have eroded the House's reputation for independence and political neutrality ${ }^{23}$ but this does not seem to be the case. The Commission does, however, appear to have served as a deterrent to unseemly appointments and, as such, reformers continue to call for the Commission to be given a more secure status by legislation. 


\section{The Parliamentary Votes on Election versus Appointment}

In the debate over reform, the most contentious issue was that of "appointment versus election," and the battle ensued over the course of three brutal debates during three different Parliaments.

The first such vote took place simultaneously in both Houses on February 4, 2003. The vote was initiated by a joint committee that had been tasked with examining a government White Paper and coming up with specific proposal. The new Joint Committee decided to submit several different options to Parliament, ranging from a fully-appointed Upper House to a fully-elected one, with various combinations in between. The debate in the House of Lords featured over 90 speakers and was dominated by those arguing for a fully-appointed House. ${ }^{24}$ The House of Commons support an elected House of Lords. ${ }^{25}$

Prime Minister Tony Blair argued against the creation of a hybrid House, and expressed his support for the House of Lords as a "revising" chamber rather than a "rival" chamber. He also highlighted that, indeed, it was a free vote but one of constitutional importance, requiring that the government have a consensus rather than a simple majority before taking any action.
The House of Commons rejected all eight options for reform, while the House of Lords voted by a 3:1 margin for a fully appointed House. MPs were most in favour of an $80 \%$ elected chamber. The result is a paradox: "By defeating eight resolutions to amend the status quo, the Commons was left with the status quo - but a status quo barely distinguishable from one of the eight defeated outcomes, and the most decisively defeated at that." 26

A number of hypotheses have been advanced to explain the vote, including the possibility that some who voted for abolition then decided to vote against all the preferred options. Alternatively, groups of MPs may have been confused on how to vote on the early motions without knowing how the vote would go on subsequent motions, or that strategic voting led groups of MPs to vote against options they would have accepted in an effort to support other options they preferred.

After interviews with members and considerable statistical analysis, one of the most likely explanations offered is that the opponents of election, rather than speaking out against the principle of election in the Upper House, agreed with the Prime Minister and advocated against the idea of a hybrid House. ${ }^{27}$

\begin{tabular}{|c|c|c|c|c|c|}
\hline \multicolumn{6}{|c|}{ February 4, 2003} \\
\hline \multicolumn{2}{|c|}{ Option } & \multicolumn{2}{|c|}{ Lords } & \multicolumn{2}{|c|}{ Commons } \\
\hline Elected & Appointed & For & Against & For & Against \\
\hline $0 \%$ & $100 \%$ & 335 & 110 & 245 & 323 \\
\hline $20 \%$ & $80 \%$ & 39 & 375 & on division & on division \\
\hline $40 \%$ & $60 \%$ & 60 & 358 & on division & on division \\
\hline $50 \%$ & $50 \%$ & 84 & 322 & on division & on division \\
\hline $60 \%$ & $40 \%$ & 91 & 317 & 253 & 316 \\
\hline $80 \%$ & $20 \%$ & 93 & 338 & 281 & 284 \\
\hline $100 \%$ & $0 \%$ & 106 & 329 & 272 & 289 \\
\hline Abolition * & & & & 172 & 390 \\
\hline
\end{tabular}


According to the chief architect of the 2003 debacle, House Leader Robin Cook,

Tony Blair's intervention brilliantly positioned a democratic second chamber as a threat to the Commons rather than a challenge to the Executive by warning that it might become a rival. He therefore conscripted enough, though not most, Labour MPs to voting for a wholly appointed Chamber. Such a Chamber will not demand any scrutiny that will trouble the Executive and will therefore not offer any hope of restoring public respect for parliamentary democracy. ${ }^{28}$

This theory is substantiated by Blair's own memoirs, where he suggests that appointment balanced by a reformed appointment process is the best way to get people with

different and deeper experience or expertise... Indeed the ministers in the Lords often turn out to be among the most able, but I doubt many, if any, would want to be put in the political apprenticeship necessary to stand for election and become an MP. ${ }^{29}$

Another Labour victory and subsequent White Paper followed, and the House again voted on the issue of House of Lords Reform in March 2007..$^{30}$ Significantly, they gained little insight from the previous experience, and once more they put forth several options in a free vote.

In this election, four of the options were defeated but a majority of MPs voted in favour of both an $80 \%$ elected chamber and a whollyelected chamber. They also supported a motion for the removal of the remaining 92 hereditary peers and for the continuance of a bicameral parliament. New leader Jack Straw expressed his satisfaction with the result, and announced that cross-party discussions would continue on the issue. ${ }^{31}$

A week later, Straw was somewhat less sanguine as the House of Lords defeated all options for an elected chamber and solidly supported the concept of an all-appointed Upper House. Asked if he would rely upon the Parliament Act to proceed without the Lords, Straw said the House of Commons could proceed that way if it wished, but that "we are not at that position yet." ${ }^{2}$

Months later, Gordon Brown replaced Tony Blair as Prime Minister and decided to introduce another White Paper on Lords Reform, but it was not well received and the issue was shelved until

\begin{tabular}{|c|c|c|c|c|c|}
\hline \multicolumn{5}{|c|}{ March 7, 2007 (House of Commons) March 14, 2007 (House of Lords) } \\
\hline \multicolumn{2}{|c|}{ Option } & \multicolumn{2}{c|}{ Lords } & \multicolumn{2}{c|}{ Commons } \\
\hline Elected & Appointed & For & Against & 196 & 375 \\
\hline $0 \%$ & $100 \%$ & 361 & 121 & - & - \\
\hline $20 \%$ & $80 \%$ & - & - & - & -155 \\
\hline $40 \%$ & $60 \%$ & - & - & 178 & 418 \\
\hline $50 \%$ & $50 \%$ & 46 & 409 & 305 & 392 \\
\hline $60 \%$ & $40 \%$ & 45 & 392 & 337 & 267 \\
\hline $80 \%$ & $20 \%$ & 114 & 336 & 416 & 163 \\
\hline $100 \%$ & $0 \%$ & 112 & 326 & 391 & 111 \\
\hline \multicolumn{2}{|c|}{ Retain Bicameralism } & - & - & & 224 \\
\hline \multicolumn{2}{|c|}{ Removal of remaining hereditary } \\
\hline
\end{tabular}


after the 2010 election. Fatigue and in-fighting among Labour members over leadership issues had taken considerable steam out of the reform movement.

A survey conducted by the Constitution Unit at University College found that election of members of the House of Lords was ranked fifth out of seven factors considered by the public to be important House of Lords reform issues. Careful consideration of legislation was regarded as a top priority, followed by a trustworthy appointments process. In addition, many people felt the Lords were doing an acceptable job of carrying out their duties compared to members of the House of Commons. ${ }^{33}$

\section{The House of Lords Reform Bill}

The 2010 election produced a Conservative-Liberal Democratic Coalition with a written agreement that favoured an elected Upper House. With the largest opposition party also in favour, it appeared that the anticipated reform was inevitable. Yet, the entire reform process came to a halt as the result of yet another vote on July 9, 2012.

This time the government proceeded differently. It presented no options and there was no free vote. It was a whipped vote on a government Bill, the House of Lords Reform Bill. It also proposed reducing membership in the Lords to 300 members. Most Lords (240) would be elected with the remaining $20 \%$ being appointed. Twelve Bishops would also sit as ex-officio members.

The bill did not propose changing the constitutional powers and privileges of the House once it is reformed, nor would the relationship with the House of Commons change.

The most controversial proposals involved how peers would be elected and the terms they would serve. Each elected Lord would serve a single, non-renewal term of three normal election cycles consisting of 15 years. The elections would be held at the same time as General Elections for the House of Commons, but would be staggered so that one-third of the seats would be contested in each election.
Appointed members would be nominated by a statutory Appointments Commission and recommended by the Prime Minister for appointment by the Queen. These Lords, like their elected counterparts, would be staggered, with 20 appointments made each election. Appointed Lords would serve the same term as elected members.

The draft Bill was sent to another joint committee. A majority, 14, endorsed the approach outlined in the Draft House of Lords Reform Bill, but 12 members signed an alternative report. One of the dissidents' main arguments was outlined by a leading authority on parliamentary government, Philip Norton, who sits in the House of Lords. He questioned whether the election process necessarily adds legitimacy to the Chamber.

If members were elected to a single non-renewable term of 15 years as proposed in the Bill, they would not face the electorate again, rendering them no more accountable or legitimate than appointees.

Another concern was that a largely elected Upper House would challenge the primacy of the Commons. The question would arise as to which elected House had more credibility. Conversely, if the Lords were to remain in its current subordinate position vis-à-vis the House, it made little sense to elect members to a chamber that had limited powers.

Another problem was the future of the crossbenchers. It was hard to imagine most of the crossbench peers, independent and extremely competent, standing for popular election. The same is true of many of the party elders who contribute their experience to the present Upper House. A PR election system could result in a membership dominated by political party influence. The resulting Upper House would become more partisan when, in its unreformed state, it often has more objective and insightful debates than the Commons.

Finally, but perhaps crucially, a few members were not prepared to move forward with the reform proposal without the benefit of a referen- 
dum. ${ }^{34}$ Labour members in particular had committed to a referendum on reform of the Lords in the 2010 Manifesto.

The Bill came to a vote after a spirited debate. The House adopted the Bill at second reading, but 91 Conservatives voted against it despite a three-line whip and the fact that 19 others abstained. When many Labour members said they would oppose a programming motion, or time allocation, requiring to have the Bill considered in committee, Deputy Prime Minister Nick Clegg announced that the whole package of Lords Reform was to be abandoned. He claimed that the Conservatives had "broken the coalition contract." Prime Minister Cameron disputed this notion, saying that the agreement contained no specific promise to enact reform of the House of Lords.

Since 2012, the reformers' efforts have continued, and a recent House of Commons Committee report and several Private Members Bills ${ }^{35}$ have focused on limited reforms most of which are aimed at reducing the overall size of the House or changing the membership in one way or another. These include:

- No longer replacing hereditary peers when they die

- Removing persistent non-attendees

- Introducing a moratorium on new appointments

- Introducing a retirement age

- Expelling peers convicted of a serious offence

- Establishing a statutory Appointments Commission

- Codifying a formula for determining the relative numerical strengths of party groups

This has left the proponents of radical reform such as election proclaiming that the whole exercise has been a failure, and vowing to redouble their efforts after the next election.

\section{Lessons for Canada}

What can Canada gain from the British House of Lords experience as we await the Supreme Court decision on the various questions posed to it by the government in October $2013^{36}$ ?

The first lesson is that we have omitted a key step on the path toward a reformed Senate in Canada. A hundred years ago the British started the process by reforming the powers of the Lords. This should be our first step, as such a debate would force us to think about the purposes we want fulfilled by our Upper Chamber.

Ideally, we require a Chamber that is not impacted by a government majority. As long as the theoretical powers of the Senate are the same as those of the House of Commons, the Prime Minister, we will be concerned about having a majority of loyal members in the Upper House and be loath to take any reforms that derogate from that.

If we were to take away the power of the Senate with a type of suspendive veto (which we already have for constitutional matters), my view is that the door would be open for a more dispassionate, reflective, and effective chamber.

A second, lesson from the British system is that incremental changes are possible but that fundamental change is more difficult. The original Harper Bill for term limits in 2006 appeared to be incrementalism. Yet, the opposition resisted in the belief, subsequently justified, that it was part of a much larger and more fundamental plan for change.

The Supreme Court could assist on the issue of term limits if it rules that this single change can be effected by Parliament alone. In so doing, it would have to overrule the Quebec Court of Appeal that has already declared that term limits would require provincial approval.

A third lesson is that Parliament must be engaged. Supreme Court hearings are a poor substitute for parliamentary debate. Our debate over Senate reform has included no White Papers, no Green Papers, no joint committees, and no special committees. The election plat- 
forms of the parties have also been vague on the issue of Senate reform. Essentially, platforms have introduced the same propositions multiple times before the government washed its hands of the matter and referred the issue to the Supreme Court.

Wider debate about whether the traditional idea of a mixed constitution is still appropriate or whether we want to go down a more populist path would be helpful. When presented with the arguments on both sides, I believe more people will side with the logic of the founders rather than the logic of the populists (be they on the left or the right).

Some, like Hugh Segal, have proposed a national referendum on this subject. Recently Preston Manning and other reformers have proposed a multi-question referendum that I suspect would produce a result similar to the 2003 British parliamentary votes - confusion. I do not think we need to go the referendum route.

The former Parliamentary Budget Officer has proposed a Royal Commission on Governance generally that could also include Senate Reform. The Harper government does not advocate for Royal Commissions in part because the previous Liberal Government used them too often to invoke delay. Yet, the British Royal Commission took less than nine months. We will receive a Supreme Court decision within that amount of time. Let us hope its decision will be taken as a starting point for a discussion rather than the last word on Senate reform.

In any event, it would be useful if our elected and appointed politicians could put their minds to Senate reform, bring out a report, and perhaps put it to a vote. Were it a free vote I expect there would be no clear consensus, but the educational value of such a debate would be important. That is why we have a Parliament, and it should be used to discuss the issues.

The fourth lesson is the need to find ways to make the Senate more independent. We should establish an "appointments commission" along the lines of the British commission either for the appointment of a limited number of Senators or for all Senators.

Like the British, we could also start the practice of alternating appointments among party leaders. Certain Caribbean commonwealth countries have written into their constitution the alternation of appointments among the Prime Minister, the Leader of the Government and the Governor General.

The recent decision by Justin Trudeau, to expel Liberal Senators from National Caucus, was a small step in the direction of independence, but much more needs to be done. ${ }^{37}$

Finally there is, of course, nothing in the British experience that helps ascertain the proper role of the provinces, and this paper has not really discussed them. But our Senate has never really been a House of the provinces. The provinces have an interest in fair representation but mainly they have the same interest as all Canadians in having a well-functioning bicameral Parliament to deal with national issues.

In all important aspects, the House of Lords provides a model of where we want to end up, but the path to getting there will not be easy.

\section{Notes}

* Fellow, Bell Chair in Parliamentary Democracy, Department of Political Science Carleton University.

1 Gary Levy, "Reform of the Upper House: Lessons from Great Britain" (Lecture delivered for the Bell Chair in Parliamentary Democracy, Carleton University, 4 February 2014), [unpublished]. This is an abridged version of the lecture.

2 Philip Norton, "Parliament and Political Parties, Speaker's Lecture Series," Democracy Live (24 January 2014), online: <http://www.bbc.co.uk/ democracylive/25879961>.

3 See Alan Burns, ed, Parliament as an Export (London: George Allen and Unwin, 1966) at 142-51.

4 Pius Msekwa, "Continuity and Change in the Westminster System of Parliamentary Government" (Paper presented to the Canadian 
Study of Parliament Group, Ottawa, 10 June 2000) [unpublished].

5 See Aristotle, Politics translated by Benjamin Jowett, <http://ebooks.adelaide.edu.au/a/aristotle/ $\mathrm{a} 8 \mathrm{po} />$.

6 "House of Lords Reform: What Next?" (London: House of Commons Political and Constitutional Reform Committee, Ninth Report of Session 2013-14) online: <http://www.parliament.uk>.

7 For a full discussion of the Parliament Act 1911 see Philip Norton, Parliament Act 1911 in its Historical Context', in David Feldman, ed. Law in Politics, Politics in Law, Hart Publishing, 2013.

8 By 2000 the party standings in the Lords were more equal. The convention was questioned and also considered by a Joint Committee on Conventions, which reported in 2006. The Committee concluded that the convention should still apply and the rejection of Bills at second reading on a regular basis would be inconsistent with the role of the Lords as a revising chamber.

9 Meg Russell, The Contemporary House of Lords (Oxford: Oxford University Press, 2013) at 84.

10 Peers are disqualified from sitting and voting in the House of Lords or serving as judges while serving as a member of the European Parliament.

11 <http://www.legislation.gov.uk/ukpga/Eliz2/6$7 / 21 /$ enacted $>$.

12 For a discussion of the role of the crossbenchers, see Meg Russell \& Maria Sciara, "Independent Parliamentarians en Masse: The Changing Nature and Role of the Crossbenchers in the House of Lords" (2009) 62:1 Parliamentary Affairs 32 at 34.

13 Members of the House of Lords can claim a daily allowance of $£ 300$ for each qualifying day or attendance and travel expenses. Only Ministers and certain office holders receive a salary under the 1975 Ministerial and other Salaries Act. The House of Lords Draft Reform Bill of 2011 proposed that members of the reformed Lords receive a taxable salary and pensions in line with provisions of the Independent Parliamentary Standards Authority, established in 2009 for the House of Commons.

14 See Meg Russell \& M Sciara, "The House of Lords in 2005: A more representative and assertive chamber?" in Michael Rush and M Giddings, eds, The Palgrave Review of British Politics (Basingstoke: Palgrave, 2006); and Meg Russell \& M Sciara, "Why Does the government get defeated in the House of Lords?” (2007) 2:3 British Politics 299 at 322.

15 UCL Department of Political Science, Government Defeats in the House of Lords, online: UCL Constitutional Unit, School of Public Policy <http://www.ucl.ac.uk/constitution-unit/ research/parliament/house-of-lords/lordsdefeats $>$.

16 See the testimony of Lord Jay of Ewelme in "House of Lords Reform: What Next?" (London: House of Commons Political and Constitutional Reform Committee, Ninth Report of Session 2013-16, 27June 2013) online:

$<$ http://www.parliament.uk>.

17 The cost of the Commission is about $£ 118997$. The major element of expenditure was staff costs, at $£ 76065$. Commission members' fees are $£ 8,000$ for the Chairman and $£ 3000$ for other members. The remainder of the expenditure was for administrative costs including travel and subsistence, staff training, publications and stationery. As a public body, the House of Lords Appointments Commission is subject to the provisions of the Freedom of Information Act, 2000.

18 See House of Lords Appointment Commission, online: <http://lordsappointments.independent. gov.uk/news.aspx $>$.

19 House of Lords, Select Committee on the Constitution, Meeting with Lord Jay of Ewelme, Chairman, House of Lords Appointment Commission, HL Paper 104 (25 January 2012) at 31 .

20 See House of Lords Appointments Commission, Annual Report October 2011 to September 2013 (October2013), online: <http://lordsappointments. independent.gov.uk/media/28825/annual $\% 20$ report\%20oct\%2011-sept\%2013\%20(pdf).pdf>.

21 House of Lords Appointments Commission, Vetting: The Role of the Appointments Commission (27 January 2014), online: <http:// lordsappointments.independent.gov.uk/vettingfor-propriety.aspx>

22 Stockbroker Barry Townsley, who had donated $£ 6000$ and loaned $£ 1 \mathrm{~m}$ on commercial terms to the Labour Party, withdrew his acceptance, as did Sir David Garrard and Sir Gulam Noon.

23 Robert Hazell, Constitutional Futures Revisited (London: Palgrave McMillan, 2008) at 293.

24 House of Lords Debates, Vol 643, No 31 (21 January 2003); House of Lords Debates, Vol 643, No 32 (22 January 2003).

25 House of Commons Debates, Vol 397, No 324 (7 January 2003).

26 See P Dorey \& A Kelso, House of Lords Reform Since 1911: Must the Lords Go? (Basingstoke: Palgrave, 2011); and I McLean, A Spirling \& M Russell, "None of the Above: The UK House of Commons 
Votes on Reforming the House of Lords," (2003) 74:3 The Political Quarterly 298 at 308.

27 Ibid.

28 Robin Cook, The Point of Departure (London: Simon and Schuster, 2003) at 280.

29 Tony Blair, Tony Blair: A Journey (New York: Alfred Knopf, 2010) at 640.

30 House of Commons Debates, Vol 458, No 59 (12 March 2007).

31 Ibid.

32 Downing Street, Afternoon press briefing, March 15, 2007. See http://downingstreetsays.com/ briefings/2007/03/15/3900)

33 House of Lords Library, Library Note: House of Lords Draft Reform Bill, LLN 2010, No 15 (28 June 2010).

34 Alan Haselhurst, "Rethinking House of Lords Reform," (2012) 35:4 Canadian Parliamentary Review 12 at 16.

35 House of Commons, supra note 5.

36 See <http://www.democraticreform.gc.ca/eng/ content/fact-sheet-reference-supreme-courtcanada-senate-reform $>$.

37 Gary Levy, "What is not to like about Justin Trudeau's Senate Reform?” (4 February 2014) The Hill Times at 20. 
